\title{
THE CONTRIBUTION OF ALAWIYYIN SCHOLARS IN GROUNDING ISLAM IN THE ARCHIPELAGO IN THE 15TH-16TH CENTURY AD
}

\author{
Dzulkifli Hadi Imawan \\ Universitas Islam Indonesia \\ Sleman, Yogyakarta, Indonesia \\ E-mail:dzulkifli.hadi.imawan@uii.ac.id \\ Labib Najib Abdullah Ghaleb \\ The University of Aden \\ Aden, Yemen \\ E-mail: Iabeeb881@gmail.com
}

\begin{tabular}{c|c|c}
\hline Received: & Revised: & Approved: \\
23/08/2021 & $22 / 10 / 2021$ & $13 / 12 / 2021$ \\
\hline
\end{tabular}

DOI : 10.32332/akademika.v26i2.3665

\begin{abstract}
This study explains the contribution of Alawiyyin Ulama in the Islamization of the archipelago in the 15-16 century AD. They have contributed a lot to the intellectualspiritual development of Islam in Islamic civilization in the archipelago. But really, their role is not widely written by historians considering the many classical scientific sources that recorded their history. Therefore, this study aims to provide new facts in revealing their contribution in spreading Islam in the archipelago through various classical literatures that record their contribution to the Islamization of the archipelago. This research was conducted using literature study; with historical analysis to find historical data and facts about the contribution of Alawiyyin scholars in the Islamization of the archipelago in the 15-16 century AD. The results of this study explain that the contribution of the Alawiyyin in the Islamization of the archipelago can be seen from their efforts to spread Islam so that civilization is born. Islam in the Archipelago. They also contributed to grounding the Ahlussunnah wa Jama'ah, the Syafii Madzhab, and Sunni Sufism in the archipelago with wisdom and wisdom.
\end{abstract}

Keywords: Alawiyyin ulama, islamization, nusantara, and 15th-16th century AD

\section{A. Introduction}

The history of Islam Nusantara is one of the most exciting studies for researchers and historians from various countries around the world, ranging from the east to the west of the world; Arabia, India, China, to Europe. The study of Islam Nusantara itself is defined as the efforts of the scholars to ground Islam in the archipelago, which was preached and taught with compassion and the ability to blend in with local culture as the teachings of Islam Rahmatan Lil Alamin exemplified by the Prophet Muhammad when preaching in Medina. ${ }^{1}$ This statement was also justified by Harisudin, that Islam

\footnotetext{
${ }^{1}$ Nurhisam, Luqman, and Huda, Mualimul. "Islam Nusantara: A Middle Way?." QIJIS (Qudus International Journal of Islamic Studies) 4, no. 2 (2016): 152-166. http://dx.doi.org/10.21043/qijis.v4i2.1763
} 
Nusantara is the face of Islam which is spread and has grounded its teachings in the archipelago. ${ }^{2}$

Among the scholars who had a great influence in the spread of Islam in the archipelago were Walisongo, the most well-known Muslim figures until today. Walisongo themselves were the descendants of Alawiyyin or Bani Alawi, who was a descendant of Sayyidina Ali bin Abi Talib, the husband of Fatimah Az-Zahra, daughter of the Prophet Muhammad from the path of Sayyid Alwi bin Ubaidillah bin Ahmad Muhajir. ${ }^{3}$ In Zumrotul Mukaffa's study, one of the scholars known as Walisongo, who was a descendant of Alawiiyyin, was Ibrahim Asmarakandi, who came from Samarkand. He succeeded in spreading Islam in the archipelago with an Islamic moral approach so that it was easily accepted by the local community. ${ }^{4}$ Unfortunately, Mukaffa seemed to still hesitate to determine whether Shaykh Ibrahim's origin was from Samarkand, Uzbekistan, or other places because he could not find any valid reference source. However, he believes that Sheikh Ibrahim contributed greatly to spreading Islam in Champa and the Archipelago. It was also believed by Khairul Azhar that one of Ibrahim Asmarakandi's descendants named Sunan Bonang and Sunan Giri studied and preached Islam in Pulau Besar, Melaka, and its surroundings. ${ }^{5}$

Likewise, according to Suparto, the scholars from Alawiyyin had succeeded in grounding Islam in the archipelago because of their sincerity and strength of faith, which were important assets in facing the challenges of Islamic da'wah in the archipelago. In addition, it was also because they were able to employ the archipelago's culture and local wisdom as a means of $d a^{\prime}$ wah that could penetrate the hearts of the people being preached to. ${ }^{6}$

Unfortunately, previous researchers have not explained where the Alawiyyin who had succeeded in spreading Islam in the archipelago came from or how they contributed to building the Islamic civilization in the archipelago and grounding Islamic thoughts following the Aqidah of Ahlu Sunnah wa Jamaah and Syafi'i's Sect (madzhab) in the field of Sharia. Therefore, the focus of this research will be on these issues, as well as the role of Alawiyin scholars in grounding Islam in the archipelago, as evidenced by various kinds of literature that previous researchers have not revealed. To achieve the objective of this article, authors conducted this research using literature study; with historical analysis to find historical data and facts about the contribution of Alawiyyin scholars in the Islamization of the archipelago in the 15-16 century AD.

${ }^{2}$ Muhammad Noor Harisudin, "Islām Wa Fiqh Nusantara: Al-Tanāfus 'Alá Al-Huwīyah Wa 'Alāqat Al-Sulțah Wa Al-Ramz Al-Dīnī Li Jam'İyah Nahdlatul Ulama," Studia Islamika 24, No. 3 (31 $1^{\text {th }}$ of Desember 2017): 503, https://doi.org/10.15408/sdi.v24i3.4324.

${ }^{3}$ Dzulkifli Hadi Imawan, The History of Islam in Indonesia; Kontribusi Ulama Membangun Peradaban Dan Pemikiran Islam Di Indonesia (Yogyakarta: Diva Press, 2021), 148.

${ }^{4}$ Zumrotul Mukaffa, "A New Account on the Potrait of Ibrahim Asmarakandi and His Sufism Approach in the Islamization of Java," Journal of Indonesian Islam 11, No. 1 (9 $9^{\text {th }}$ of Juli 2017): 175, https://doi.org/10.15642/jiis.2017.11.1.175-200.

${ }^{5}$ Khairul Azhar Meerangani, "Peranan Ulama Dalam Penyebaran Ajaran Islam Di Pulau Besar, Melaka (The Role of Muslim Scholars in Spreading the Teaching of Islam in Pulau Besar, Melaka)," Journal of Al-Tamaddun 14, No. 2 (17 th of Desember 2019): 65-74, https://doi.org/10.22452/jat.vol14no2.6.

6 Suparto Suparto, Halid Halid, and Samsu Adabi Bin Mamat, "Bani Alawiyyin in Indonesia and the Malay World: Network, Development and the Role of Institution in Transmitting the Peaceful Mission of Islam," Journal of Indonesian Islam 13, No. 2 (1 $1^{\text {st }}$ of December 2019): 267, https://doi.org/10.15642/jiis.2019.13.2.267-296. 


\section{B. The Islamization and the Entry of Alawiyyin Scholars to the Archipelago}

The history of when Islam entered and who brought it to the archipelago has various opinions among historians. According to Pij Nappel from Leiden University, Islam in the archipelago originated from Gujarat and Malabar because there was a group of Arabs who followed the Shafii's madzhab and propagated it across the Archipelago. This viewpoint was supported by Snouck Hurgronje, who also suggested that preachers from Malabar might have arrived in the Archipelago in the $12^{\text {th }}$ century AD to spread Islam. ${ }^{7}$ Unfortunately, this argument was dubious, because Arnold claimed that Islam expanded throughout the Archipelago in the first century of Hijri. This was feasible due to a long-standing trading tie between the archipelago and the Arab world. Furthermore, Arab traders dominated the trading hubs in Sri Lanka (Sailan), Canton-China, allowing them to access the Archipelago. ${ }^{8}$

Furthermore, Arnold's explanation corresponded to historical facts reported in trip literature of Arabs who arrived in the Archipelago far before the 12th century AD. Sulaiman al-Tajir, al-Sairafi, from the city of Sairaf in Iran, Persia, was one of them. In the 9th century AD, he landed in the Archipelago as an Arab Muslim trader. In his book 'Ajaib al-Dunya,' he wrote of his adventures while traveling in the Archipelago approximately $237 \mathrm{H}$ or $851 \mathrm{AD}$. He sailed from al-Khalij in the Arabian Gulf to India, China, and finally the Archipelago. Furthermore, he had stopped in the Kulah Baar Archipelago, specifically Mamlakah Zabij, on the right side of India, on his trip around the world. They wore clothes such as towels (al-fuwath), scarves, or jarik. In this country, there were wells with very freshwater that they used for their daily needs, and they preferred healthy water to rainwater (unlike the Arabs, who were very happy with rainwater because it rains very rarely there). 9

In addition, records about the archipelago in the 9th century AD were also recorded by Abu Qasim Ubaidillah bin Abdullah Ibn Khurdadzbih (820-912 AD); a historian and geographer from Khurasan. In his book entitled al-Masalik wa al-Mamalik, and he called the archipelago as Zabij and called its king as Maharaja. ${ }^{10}$ Interestingly, a century later, precisely in the 10th century AD, an Arab historian named Abu Hasan Ali bin Husain Ali al-Mas'udi (d.346 H / 957 AD), in his book Muruj adz-Dzahab wa Ma'adin al-Jauhar also once recorded the archipelago as Mamlakah Maharaja which was located in Bahr al-Shinfi and referred to its king as Malik al-Jazair. The king had many armies and many perfumes like kafur; camphor, 'aud; agarwood, qaranfu; cloves, as well as many other spices. He also recounted the beauty of the archipelago, which has many islands and is connected to a very wide sea, as if it were endless, many volcanoes are visible both at night and during the day, as if they were one with the sky, and has clear flowing rivers (as depicted in heaven in the Qur'an), which is very rare in Arab countries (Al-Taubah: 72, An-Nisa: 122). ${ }^{11}$

Arab historians' records were some pieces of proofs that Islam in the archipelago did not come from Malabar and Gujarat, but rather from Arab countries, which

${ }^{7}$ Azumardi Azra, Jaringan Ulama Timur Tengah Dan Kepulauan Nusantara Abad Xvii \& Xviii (Jakarta: Prenada Media Grup, 2013), 2.

8 Sir Thomas Walker Arnold, Al-Da'wah Ila Al-Islam; Bahts Fi Tarikh Nasyri Al-'Aqidah AlIslamiyah, Trans. by Hasan Ibrahim Hasan and Abdul Majid Abidin, Iii (Kairo: Maktabah Nahdlah Mishriyah, 1935), 401.

${ }_{9}$ Al-Sairafi, 39.

${ }^{10}$ Abu Qasim Ubaidullah Bin Abdullah Ibnu Khurdadzbah, Al-Masalik Wa Al-Mamamlik (Leiden: Briel, 1889), 68.

11 Abu Hasan Ali Bin Husain Bin Ali Al-Mas'udi, Muruj Adz-Dzahab Wa Ma'adin AlJauhar, I (Beirut: Maktabah 'Ashriyah, 2005), 119-20. 
scholars and Arab Muslim traders carried with them.

In the 9th century $\mathrm{AD}$, it was the golden age of the Abbasid civilization, which was headquartered in Baghdad under the leadership of Amirul Mukminin Harun arRashid. Under his leadership, Baghdad became a center of education as well as an economic hub. Baghdad, with its Baitul Hikmah (House of Wisdom), was founded by Abu Ja'far al-Mansur Abdullah bin Muhammad bin Ali bin Abdullah bin Abbas bin Abdul Muttalib bin Hasyim (d. 775 AD), developed rapidly during the time of Harun ar-Rashid (d. 809 AD), and advanced during the time of Abdullah Al-Mamun (d.833 AD), and became the world's intellectual-spiritual.12 Baghdad was also a crossroads for traders from all over the world, which had resulted in the formation of Arab adventurers who sailed to discover new lands. Besides, they also had missions, one of which was to trade and preach the message of Islam. ${ }^{13}$

Interestingly, the spread of Islam in the archipelago after Sairafi (9th century AD) and Mas'udi (10th century AD) was mostly carried out by scholars from the Alawiyyin circles. This was as explained by al-Idrisy, one of the clerics descended from Sayyidina Hasan bin Ali bin Abi Talib. He, whose full name was Syarif Abu Abdillah Muhammad bin Muhammad bin Abdullah bin Idris al-Hasani, was a sailor and also an Arab scholar who had succeeded in reaching the archipelago in the 6th century $\mathrm{H}$ or coinciding with the 12th century AD. In his book entitled Nuzhatu al-Musytaq fi Ikhtiraq al-Afaq which he wrote in $1154 \mathrm{AD}$, he explained in the book that in the archipelago he had visited the land of Waq-Waq; inhabited by black and unclothed residents ('uryan that later named Irian). This area is now Papua. At that time, this country did not have many merchants and ships that stopped here. ${ }^{14}$

Idris's experience in reaching the archipelago became a special motivation for Islamic scholars from the Alawiyyin family. Even one of the scholars from Damascus named Syamsuddin Abu Abdillah Muhammad Abi Talib al-Ansari al-Damasyqi (w.727 H / 1327 AD) who had succeeded in reaching the archipelago after Idrisy emphasized in his book Nukhbah ad-Dahr fi 'Ajaib al-Barr wa al-Bahr, that the scholars of Alawiyyin had a major contribution in the spread of Islam in the archipelago or what he called the kingdoms in the far east (al-Mamalik al-Masyriqiyyah). ${ }^{15} \mathrm{In}$ fact, according to him, Alawiyyin, or the descendants of Sayyidina Ali bin Abi Talib had reached the archipelago and spread Islam there since the reign of the kingdom of Umawiya in Damascus. ${ }^{16}$ Since then, the Alawiyyin scholars continued to arrive and become pioneers of $d a^{\prime} w a h$ in the archipelago, especially in Java; one of the largest islands in the archipelago, which has beautiful scenery and fertile soil with high rainfall, and produces many crops in the form of fruits, spices, various fragrances, and also has various types of animals.

According to Husain Muknis, Islamization in Java began in the 9th century AD,

${ }^{12}$ A.M. Abdulaziz Algeriani Dan M. Mohadi, “The House Of Wisdom (Bayt Al-Hikmah), An Educational Institution During The Time Of The Abbasid Dynasty. A Historical Perspective," Pertanika Journal Of Social Sciences And Humanities 27, No. 2 (2019): 1297.

13 Kusmana Kusmana, "Al-Tijārah Wa Al-Da'wah Al-Islāmīyah: Dirāsah Li Qaḍiyati

Dukhūl Al-Islām Fī Indūnīsīyā," Studia Islamika 7, No. 3 (2000), https://doi.org/10.15408/sdi.v7i3.704.

14 Syarif Abu Abdillah Muhammad Bin Muhammad Bin Abdullah Bin Idris Al-Hasani Al-Idrisiy, Nuzhatu Al-Musytaq Fi Ikhtiraq Al-Afaq (Kairo: Maktabah Tsaqafah Diniyyah, 2002), 80-84.

${ }^{15}$ Syamsuddin Abu Abdillah Muhammad Abu Thalib Al-Anshari Al-Damasyqi, Nukhbah Al-Dahr Fi 'Ajaib Al-Barr Wa Al-Bahr (Turs: Matba'ah Imritoriyah, 1881), 167-68.

16 Al-Damasyqi, 168. 
followed by the Islamization in Peureulak in the 12th century AD, Samudera Pasai in the 12th century AD, and Aceh Darussalam in the 15th century AD. However, this viewpoint differed with De Graaf and Pigeaud, who claimed that Islamization in Java happened during the 11th and 13th centuries AD, after the Peureulak kingdom. They reasoned that the Land of Java at the time was an island crossed by numerous foreign traders, both Muslims and non-Muslims. As a result, Muslim traders who stopped in Java at the time or even lived there were able to do so. Moreover, two cities in Java such as Gresik and Surabaya, at that time had big ports that became the ports for various ships from abroad, so that these two cities became the entry gates for the spread of Islam in Java. This statement was confirmed by the existence of the tomb of Fatimah daughter of Maimun, who died on 7 Rajab 475 H or 1082 AD (11th century AD), and the tomb of Maulana Malik Ibrahim, who died in $822 \mathrm{H} / 1419$ AD (15th century AD). Both two tombs are located in Leran, Gresik, East Java. ${ }^{17}$

According to Hamid, the contribution of Alawiyyin in grounding Islam in the archipelago began at the end of the 6th century $\mathrm{AH}$ or the beginning of the 13th century AD. At that time, there was a Khawarij rebellion that attacked the city of Tarim, Hadramaut. Due to this incident, Sayyid Abdul Malik bin Alawi along with many other Alawiyyin families left Tarim for India. In this country, their descendants then spread in several places such as Buruj, Ahmad Abad, and surrounding areas. These places came to be known as Gujarat. ${ }^{18}$ In this place, they became a large community and succeeded in developing the country's economy and politics. ${ }^{19}$

According to Ali Masyhur, Sayyid Abdul Malik was a cousin of Sayyid Muhammad bin Ali al-Faqih al-Muqaddam (564-653 H/1169-1255 AD); ${ }^{20}$ one of the reformers in Tarim in the 6th century $\mathrm{H}$ or the 13th century AD. Their grandfather was al-Imam Sayyid Muhammad bin Ali bin Alawi Khali 'who was known as Shahib Mirbath. He had four sons named Ali, Alawi, Abdullah, and Ahmad. Al-Faqih alMuqaddam was the only son of Sayyid Ali, while Abdul Malik was the son of Sayyid Alawi (d.613 AD) with two other brothers named Sayyid Ahmad bin Alawi and Sayyid Abdurrahman bin Alawi. ${ }^{21}$

As for Hamid, Sayyid Abdul Malik, when he was in India, had a son named Abdullah who later became an influential leader in the Kingdom of India. In fact, he had ten thousand troops, so he was later given the title Azhamat Khan. Sayyid Abdullah Azhamat Khan had a son named Sayyid Ahmad Syah Jalal bin Abdullah 'Azhamat Khan, who was later appointed by the king of India as a minister. The word Jalal itself is a reference to the city of Jalal Abad in Gujarat. When there was slander in India in the 8th century H or the 14th/15th century AD, the sons of Sayyid Ahmad Syah named Sayyid Jamaluddin bin al-Husain, Sayyid Barakat Tsanauddin, Sayyid Yahya Kamaluddin, Sayyid Ali Muhyiddin Amir, Sayyid Amir Ibrahim al-Mujahid, Syarif Ghazi Zainuddin, Amir Ahmad Ali, Amir Abu Abdillah, Nasir Syifaul Arifin, Saladin

17 H.J De Graaf and Th Pigeaud, Kerajaan Islam Pertama Di Jawa; Tinjauan Sejarah Politik Abad Xv Dan Xvi; De Eerste Moslimse Vorstendommen Op Java, Studien Over De Staatkundige Geschiedenis Van De 15 De En 16 De Euw, Ed. Eko Endarmoko and Jaap Erkelens, Iv (Jakarta: Grafiti, 2001), 22.

18 Al-Hamid, Rihlah Jawa Al-Jamilah Wa Qisshah Dukhul Al-Islam Ila Syarq Asia, 15.

19 Suparto, Halid, and Mamat, "Bani Alawiyyin In Indonesia And The Malay World," 267.

${ }^{20}$ Abu Bakar Al-'Adani Ali Al-Masyhur, Al-Ustadz Al-A'zham Al-Faqih Al-Muqaddam (574653 H), Ii (Adn: Markaz Al-Ibda' Al-Tsaqafi, 2003), 116.

21 Abu Bakar Al-'Adani Ali Al-Masyhur, Al-Imam Muhammad Shahib Mirbath (Adn: Markaz Al-Ibda' Al-Tsaqafi, 2002), 25-26. 
Muhammad, Sultan Akbar Nur, together with their wives, families, and servants, then left India. 22

According to Ja'fari, Sayyid Jamaluddin al-Husain, one of Sayyid Ahmad Shah's sons, then moved from India to the east with his ship called Barakatul Islam. His ship then stopped at Campa after he learned that there were many Muslims who stopped or lived there. Campa when viewed from the sea route was a place halfway between India and China, so it became an important place for traders to rest. When Sayyid Jamaluddin was in Campa, he met his king, Jayavarman VII. There was a long discussion that led to the agreement of King Jayavarman VII with Sayyid Jamaluddin to help each other in dealing with the Siamese troops led by Paramkaya, who wanted to control the country of Campa. With the help of Sayyid Jamaluddin and his son Sayyid Ibrahim and his students, King Campa managed to defeat the Siamese troops, which had a good impact on his relationship with Sayyid Jamaluddin, so he was invited to stay in Campa. Since then, Islam that was taught by Sayyid Jamaluddin has grown in the country of Campa. As time went on in Campa, Sayyid Ibrahim, the son of Sayyid Jamaluddin, later married the daughter of King Jayavarman VII named Candrawulan. This marriage took place solemnly and sacredly because this was the first marriage that took place in Campa between an Arab descendant of the Prophet Muhammad and a native of Campa so that he was later called Sayyid Ibrahim Asmara. From this marriage, Sayyid Ibrahim was blessed with two children named Ali Rahmatullah and Ishaq. ${ }^{23}$

The data illustrated by Ja'fari was different from what was conveyed by Mukaffa, who said that Ibrahim Samarkandi came from Samarkand, Uzbekistan. ${ }^{24}$ However, Mukaffa's data was very weak. Even, he doubted and did not show any convincing literature stating that Sayyid Ibrahim Asmara came from Samarkand. His opinion was refuted by the information submitted by Hamid and Ja'fari, who has shown that Ibrahim Asmarakandi came of the Alawiyyin descent and he came from Yemen, not Uzbekistan.

Ja'fari then explained, Sayyid Jamaluddin with his three sons, Sayyid Ibrahim, Sayyid Ali Nur Alam, and Sayyid Barakat, preached in various cities in the archipelago. They moved from Campa to Sarawak eastward to Makassar, then Madura, and finally landed in Leran, Gresik, Java. In Java, he became the communication liaison between King Kertanegara Singosari and King Jayavarman VII Campa. From here, he was allowed to live in Ampel and was known by the Javanese people as Sayyid Jumadil Kubra. From Java, Sayyid Jamaluddin then preached to Maluku, Bugis, and Wajo until he died in $736 \mathrm{H}$ or 1335 AD. ${ }^{25}$ The da' wah that had been initiated by Sayyid Jamaluddin al-Husain was then continued by his students until there was a Kutai King who embraced Islam and changed its name to Sultan Idris. ${ }^{26}$

His two sons, Sayyid Ali Nur Alam and Sayyid Barakat, continued to preach in Java. As for Sayyid Ibrahim, he headed east until he arrived in Mindanao, the Philippines. In this city, at that time, there were many tribes. Each tribe had a leader. Thus, this supported Sayyid Ibrahim in teaching Islam, especially when interacting

22 Al-Hamid, Rihlah Jawa Al-Jamilah Wa Qisshah Dukhul Al-Islam Ila Syarq Asia, 21.

23 Bassyar Al-Ja'fari, Auliya Al-Syarq Al-Ba'id Asathir Majhulah Fi Aqadli Al-Ma'murah; Riwayat Tarikhiyah Haula Kaifiyyah Intisyar Al-Islam Fi Arkhabil Al-Malayu, I (Damaskus: Dar Thalas, 2002), 245.

${ }^{24}$ Mukaffa, "A New Account on the Potrait of Ibrahim Asmarakandi and His Sufism Approach in Islamization of Java," 175.

${ }^{25}$ De Graaf and Pigeaud, Kerajaan Islam Pertama Di Jawa, 23.

${ }^{26}$ Al-Hamid, Rihlah Jawa Al-Jamilah Wa Qisshah Dukhul Al-Islam Ila Syarq Asia, 21. 
with them. He put forward the nobility of morality so that this attitude attracted them to know the teachings brought by Sayyid Abraham. Because of his preaching, many people converted to Islam. He married a second time to an indigenous daughter there and had a child named Paramaisuli. ${ }^{27}$ This daughter was later married by a student named Syarif Maraja or Syarif Maharaja, who later had two sons named Tabu Nawi and Mamalo, respectively. Both were then educated by Syarif Muhammad bin Ali Zainal Abidin. 28

After preaching in Mindanao, he returned to Campa and returned to Java with his sons, Ishaq and Ali Murtadla, to meet his two brothers, Sayyid Ali Nur Alam and Sayyid Barakat. Meanwhile, his third son, Ali Rahmatullah, remained in Campa to help his mother, Candrawulan, and was assisted by his two nephews; Sayyid Barakat's son, Malik Ibrahim, and Ali Nur Alam's son, Abdullah. ${ }^{29}$

Sayyid Ibrahim Asmara then divided the task of $d a^{\prime} w a h$ to his children. Sayyid Makhdum Ishaq was sent to preach in Samudera Pasai, while Sayyid Ali Rahmatullah was sent to preach in Java. Maulana Sayyid Makhdum Ishaq bin Sayyid Ibrahim was known as a scholar who was very ascetic and very simple in terms of clothing and food but very knowledgeable in scientific matters. He had preached on the island of Java and lived for some time at the place of his brother Sayyid Ali Rahmatullah or Sunan Ampel. Not only that, but Syarif Makhdum Ishaq was also known as waliyullah whose prayers were known to be efficacious. Every time he prayed for a sick person, then Allah healed that person instantly. This was one of Allah's help when he preached Allah's religion. From Java, he went on to preach in Malacca and Johor and succeeded in inviting the king to convert to Islam so that the king later had the title Sultan Muhammad Syah bin Sultan Iskandar Syah. ${ }^{30}$

Ja'fari explained that when Sayyid Makhdum Ishaq preached in Malacca in 800 H/1398 AD. At that time, Malacca was still led by King Paramaisuwara, who was Hindu. He originally came from Tumasik, who fled from the pursuit of the Siamese troops. So when he was met by Sayyid Makhdum Ishaq, he was invited to leave his old religion and embrace Islam. When he converted to Islam, he changed his name to Sultan Muhammad Iskandar Syah, then married the daughter of the king of Perlak Sultan Makhdum Alauddin Malik Muhammad Amin Shah II. Islam then quickly spread in the Johor region, and even Malacca later became a new power as the center of trade traffic in the archipelago at that time. Sayyid Makhdum Ishaq died in $805 \mathrm{H} .{ }^{31}$

Meanwhile, in Ampel, Islamic da'wah was continued by Sayyid Ali Rahmatullah bin Ibrahim bin Jamaluddin al-Husain, who was believed to have come to Java for the first time when he was twenty years old in $804 \mathrm{H}$ or $1401 \mathrm{AD}$, three years earlier after Sayyid Syarif arrived in 801 AH or 1398 AD with his son and brothers. ${ }^{32}$

Sayyid Ali Rahmatullah's arrival was accompanied by his friend Abu Hurairah al-Mujahid; a son of King Campa who was a student of Sayyid Ibrahim; Sayyid Ali Rahmatullah's father. Abu Hurairah had a big role in helping Sayyid Rahmatullah or Sunan Ampel in the spread of Islam in Java. It was he who was sent by Sultan Abdul Fattah or Raden Patah to appear before King Brawijaya V, the ruler of Majapahit, to invite him to convert to Islam. He was also involved in open debates with Buddhist

\footnotetext{
27 Al-Ja'fari, Auliya Al-Syarq Al-Ba'id, 285.

28 Thahir Al-Haddad, Al-Madkhal Ila Tarikh Al-Islam, 278-79.

${ }^{29}$ Al-Ja'fari, Auliya Al-Syarq Al-Ba'id, 300.

30 Thahir Al-Haddad, Al-Madkhal Ila Tarikh Al-Islam, 279.

31 Al-Ja'fari, Auliya Al-Syarq Al-Ba'id, 344.

32 Thahir Al-Haddad, Al-Madkhal Ila Tarikh Al-Islam, 280.
} 
clergy and was able to defeat them in the debate with strong arguments, especially on the issue of human equality in Islam and Buddhism. ${ }^{33}$

Sayyid Ali Rahmatullah also preached in Palembang, which at that time was led by Aryadamar, son of King Wijaya. It was said that King Wijaya once married a woman, the daughter of a leader in Jambi, to strengthen the relationship between the two. The princess was a new convert to Islam which made the other queen angry and jealous and forced her husband (King Wijaya) not to marry her. Under these conditions, the king then sent the princess to his son, Arya Damar, who became the ruler of Palembang, to be willing to marry her. Once after Arya Damar converted to Islam, Sayyid Ali Rahmatullah was given the title Raden Rahmatullah. Since then, the Palembang Kingdom subsequently became an Islamic kingdom following the Islamic kingdoms in Sumatra, such as Peureulak and Samudera Pasai. At that time, the Kingdom of Samudera Pasai was under Sultan Malik Ahmad bin Sultan Muhammad Malik Zahir, who had a lot of diplomatic relations with Islamic kingdoms in Sumatra, including Palembang, which was led by Sultan Abdullah (Aryadamar). ${ }^{34}$

After preaching in Palembang, Raden Ali Rahmatullah then returned to Ampel and built a pesantren (Islamic boarding school) in Ampel. Here, many students studied Islam with him, including Abdul Fattah and his brother's son Sayyid Muhammad Ainul Yaqin bin Maulana Makhdum Ibrahim (Sunan Giri) and many students from the surrounding community, until he was called as Sunan Ampel. He settled in Ampel until he died in 1479 AD. Sayyid Ali Rahmatullah's cousin or Sunan Ampel named Sayyid Malik Ibrahim bin Barakat bin Sayyid Jamaluddin al-Husain was also a person who played an important role in the process of Islamization in Java. He spread the religion of Islam in Leran, Gresik, until the end of his life and died in 822 H/1419 AD. Many gravestones were brought from Cambay at the time, according to the inscription on his marble tombstone. ${ }^{35}$ According to Fournie, the pesantren built by Sunan Ampel was the forerunner of an Islamic religious school in Java that succeeded in combining Islamic material with local culture, ${ }^{36}$ and this would later contribute greatly to the formation of the nation's culture. ${ }^{37}$

The role of Islamization of Java was then continued by the descendants of Sunan Ampel such as Maulana Ibrahim or Sunan Bonang, Sayyid Hasyim, Maulana Sayyid Ja'far Sadiq (Sunan Kudus), Maulana Zainul Abidin, and Sayyid Abdusshamad. While the descendants of Azhamat Khan from the lineage of Maulana Ishaq bin Ibrahim bin Jamaluddin al-Husain were continued by Abdul Qadir al-Fasi; attributed to Samudera Pasai in Aceh, Muhammad Ainul Yaqin, Maulana Ibrahim bin Ishaq, and Hasan Askari, as well as Sayyid Sulaiman bin Sayyid Ali Murtadla bin Sayyid Ibrahim bin Jamaluddin al-Husain. ${ }^{8}$

Sunan Ampel's student, who was also his nephew, was named Sayyid Muhammad Ainul Yaqin bin Sayyid Makhdum Ishaq. He contributed greatly to the

${ }^{33}$ Al-Hamid, Rihlah Jawa Al-Jamilah Wa Qisshah Dukhul Al-Islam Ila Syarq Asia, 22.

34 Al-Ja'fari, Auliya Al-Syarq Al-Ba'id, 300.

35 Elizabeth Lambourn, "From Cambay to Samudera-Pasai and Gresik-The Export of Gujarati Grave Memorials to Sumatra and Java in the Fifteenth Century C.E.," Indonesia and the Malay World 31, No. 90 (1 ${ }^{\text {st }}$ of July 2003): 221-84, https:/ / doi.org/10.1080/1363981032000165903.

36 P. Fournié, "Rediscovering the Walisongo, Indonesia: A Potential New Destination for International Ilgrimage," International Journal of Religious Tourism and Pilgrimage 7, No. 4 (2019): 77 .

37 Widhiya Ninsiana, "Islam dan Integrasi Sosial dalam Cerminan Masyarakat Nusantara," Akademika : Jurnal Pemikiran Islam 21, No. 2 (16 Oktober 2016): 237.

38 Al-Hamid, Rihlah Jawa Al-Jamilah Wa Qisshah Dukhul Al-Islam Ila Syarq Asia, 24. 
Islamization of Java. He preached and founded a pesantren in Giri to teach Islamic religious sciences to his students until he was known as Sunan Giri. ${ }^{39} \mathrm{He}$ was also known as a scholar who was an expert in the science of aqidah and figh.40 Among the students of Sunan Ampel, who was known as the founder of the first Islamic kingdom in Java, was Raden Fatah. It was he who founded the Demak Kingdom in 1478 and ruled until 1518.41 This also confirmed that the Alawiyyin scholars had a very large contribution to building a civilization in the archipelago, either through their descendants or through their students.

As for the Malay Archipelago and Mindanao, the teaching of Islamic religious sciences was carried out by Sayyid Zainal Abidin, Sayyid Muhammad Kabungsuan, and Sayyid Abu Bakar; student of Sayyid Makhdum Ishaq.42 According to Ja'fari, Sayyid Zainal Abidin was a descendant of Abdullah bin Alawi bin Muhammad Shahib Mirbath. Sayyid Abdullah was the brother of Sayyid Abdul Malik who was the progenitor of Sayyid Jamaludin al-Husain. The complete lineage was Sayyid Zainal Abidin bin Ahmad bin Abdullah bin Muhammad bin Ali bin Abdullah bin Alawi bin Ali bin Muhammad bin Alawi bin Muhammad bin Abdullah bin Ahmad bin Isa bin Muhammad bin Ali bin Ja'far Sadiq bin Muhammad Baqir bin Zainal Abidin bin Husain bin Ali bin Abi Talib. ${ }^{43}$

Sayyid Zainal Abidin first visited Malacca. Here, in addition to trading, he also preached to teach Islam to the local population. Finally, he married the king's daughter named Jasul Asiqin. From this marriage, he was blessed with four sons, each named Ali, Muhammad al-Akbar Kabungsuan, Muhammad al-Ashghar, and Hasan Zainal Abidin. Sayyid Zainal Abidin himself was later appointed to be qadli in the Kingdom of Malacca. To prepare his potential successor in preaching, he then sent his son named Abu Bakr to study in Mecca. Only a year in Mecca, he returned to Malacca. He then preached and taught Islamic religious sciences and wrote a book al-Durr al-Manzhum, which described ninety religious issues as a guide for the king in enforcing the law. He was a student of Shaykh Abu Ishaq al-Syairazi in Mecca at that time. ${ }^{44}$

Ja'fari also explained that the Malacca Kingdom reached the peak of its glory during the reign of Sultan Qasim Muzaffar Shah, the successor of his father Sultan Iskandar Syah Dzulqarnain (d. $823 \mathrm{H}$ ). At the same time, Sultan Salahuddin died in Aceh, who was later succeeded by his son Abdullah, who married his uncle's daughter, Bahiyah bint Sultan Ali Zainal Abidin. Seven years later, Sayyid Zainal Arifin died in $830 \mathrm{H}$. Sayyid Zainal Abidin's preaching was continued by his sons in various places such as Mindanao, Brunei, and Sulu Sindaken. His da'wah was then followed by Sayyid Abu Bakr, who went to Sulu to meet his brothers. When he arrived in Sulu, he was greeted by King Sultan, who was a descendant of Sayyid Jamaluddin al-Husain. Therefore, he was later made qadli in his kingdom and imam at the Jami mosque. After His Majesty King died and had no male heir, Sayyid Abu Bakar was then appointed as his successor with the title Paduka Maha Sari Maulana Sultan Syarif al-Hashimi. At this

39 Al-Ja' fari, Auliya Al-Syarq Al-Ba'id, 348-49.

40 Ahmad Yusuf Setiawan, "Karya Sastra Sunan Giri dalam Perspektif Dakwah Islam,"

An-Nida: Jurnal Komunikasi Islam 7, No. 2 (2nd of July 2015), https:// doi.org/10.34001/an.v7i2.755.

${ }^{41}$ Agus Susilo and Ratna Wulansari, "Peran Raden Fatah dalam Islamisasi di Kesultanan Demak Tahun 1478-1518," Tamaddun: Jurnal Kebudayaan dan Sastra Islam 19, No. 1 (28 $8^{\text {th }}$ of June 2019): 70, https://doi.org/10.19109/tamaddun.v19i1.3401.

42 Thahir Al-Haddad, Al-Madkhal Ila Tarikh Al-Islam, 281.

43 Al-Ja'fari, Auliya Al-Syarq Al-Ba'id, 351.

44 Al-Ja' fari, 352. 
time, Islamic law could run and be accepted by the local community. 45

This note was also believed by Meerangani that the Alawiyyin scholars played a major role in the spread of Islam in Malacca. This was also confirmed by Khairul Azhar, if Sunan Giri, son of Maulana Ishaq and Sunan Bonang, son of Maulana Rahmatullah, contributed to the spread of Islam in Malacca at that time. ${ }^{46}$ The Islamization of Malacca by the Alawiyyin scholars also helped encourage the local community to build mosques in Malacca. ${ }^{47}$

In addition, in the notes of Ahmad al-Saqqaf, Tarikh al-Islam fi Banten, among the descendants of Azhamat Khan who played a role in the spread of Islam in Java; especially West Java from Cirebon to Banten, was Syarif Hidayatullah or known as Sunan Gunung Jati. His lineage was Maulana Sharif Hidayatullah bin Raja 'Umdah alDin Campa bin Ali Nur Alam bin Maulana Jamaluddin al-Husain al-Akbar bin Sayyid Ahmad Shah bin Abdullah 'Azhamat Khan bin Abdul Malik bin Sayyid Alawi bin Sayyid Muhammad Shahib Mirbath bin Sayyid Ali Khali' bin Sayyid Alawi bin Sayyid Muhammad bin Sayyid Alawi bin Abdulah bin Imam Ahmad bin Isa bin Imam Isa bin Imam Muhammad bin Imam Ali Uraidli bin Imam Ja'far Sadiq bin Imam Muhammad Baqir bin Sayyid Ali Zainal Abidin bin Sayyidina Husayn bin Ali bin Abi Talib with Fatimah al-Zahra' daughter of the Prophet Muhammad. ${ }^{48}$

From the lineage, it can be seen that Sunan Gunung Jati was also a descendant of Sayyid Jamaluddin Husain so that he still had kinship ties with Sunan Giri and his father Makhdum Ishaq and Raden Rahmat or Sunan Ampel and Sunan Gresik; Maulana Malik Ibrahim. According to Ja'fari, at first, he lived in the Kingdom of Samudera Pasai and then studied at Mecca al-Mukarramah. After returning from Mecca, he headed to Pasai and then to Demak and became one of the scholars who were close to Sultan Trenggono. ${ }^{49}$ Interestingly, in Farida's study, it was stated that the synergy between the ulama and the Kings of Demak succeeded in strengthening Islamic teachings in various fields such as faith, worship, as well as in the fields of education, economy, military, government, art, law, and social society. ${ }^{50}$

The Islamization carried out by Alawiyyin scholars in the archipelago succeeded in grounding Islamic teachings and upholding Islamic norms in various aspects of life, ${ }^{51}$ integrating Islamic teachings with local culture, 52 and creating a society of peace, compassion, and mutual respect for one another. ${ }^{53}$ Besides, they also contributed to

${ }^{45}$ Al-Ja'fari, 356.

${ }^{46}$ Meerangani, "Peranan Ulama dalam Penyebaran Ajaran Islam di Pulau Besar, Melaka (The Role of Muslim Scholars in Spreading the Teaching of Islam in Pulau Besar, Melaka)."

47 "Malacca Mosque: The Aesthetics of Old Mosques in Malaysia | Mediterranean Journal of Social Sciences," $5^{\text {th }}$ of August 2020, https://www.richtmann.org/journal/index.php/mjss/article/view/5216.

${ }^{48}$ Ahmad Al-Saqqaf, Tarikh Al-Islam Fi Banten; Al-Mukhtar Al-Mashun Min 'Alam Al-Qurun Mukhtarat Tis'ah 'Asyara Kitaban (Jeddah: Dar Andalus Khadra', N.D.), 895.

${ }^{49}$ Al-Ja' fari, Auliya Al-Syarq Al-Ba'id, 370.

${ }^{50}$ Umma Farida, "Islamisasi di Demak Abad Xv M: Kolaborasi Dinamis Ulama-Umara dalam Dakwah Islam di Demak," Accessed on $1^{\text {st }}$ of November 2021, https://doi.org/10.21043/at-tabsyir.v3i2.1649.

51 Haedar Nashir amd Mutohharun Jinan, "Re-Islamisation: The Conversion of Subculture from Abangan into Santri In Surakarta," Indonesian Journal of Islam And Muslim Societies 8, No. 1 (2nd of July 2018): 1-28, https://doi.org/10.18326/ijims.v8i1.1-28.

52 Amrizal Amrizal, "Dimensi Sufistik dalam Pandangan Hidup Orang Melayu," Akademika : Jurnal Pemikiran Islam 21, No. 2 (16 ${ }^{\text {th }}$ of October 2016): 275-90.

53 A. Gani, "Pendekatan Sufistik dalam Pendidikan Islam Berwawasan Perdamaian," Akademika : Jurnal Pemikiran Islam 23, No. 2 (25th of November 2018): 387-412. 
building civilization and became advisors (mufti) in the kingdoms of the archipelago.

\section{Grounding the Aqidah of Ahlussunnah wal Jama'ah, Shafi'i's Madzhab, and Sunni Sufism}

The Alawiyyin scholars not only contributed to building Islamic civilization in the archipelago, but they also contributed greatly to the process of spreading the Aqidah of Ahlussunnah wal Jama'ah, Syafii's madzhab, and also Sufism Sunny. As explained by Habib Zain Sumaith, from the beginning, the scholars of the descendants of Sayyid Alawi bin Abdullah bin Ahmad bin Isa al-Muhajir had followed the Shafii's madzhab. Especially when Sayyid Ahmad Isa al-Muhajir moved from Basrah to Hadramaut in 319 AH / 931 AD, he played a major role in the spread of the Shafii's madzhab in Yemen. ${ }^{54}$ Among the evidence for the contribution of Alawiyyin scholars in maintaining the Shafii's madzhab as the mainstream of Islamic legal thought in Hadramaut was that there were many books of the Shafii's madzhab that they wrote, such as the books written by Imam Abdullah bin Abdurrahman Baubaid (d. 603 H/1206 AD), Imam Muhammad al-Faqih al-Muqaddam bin Ali bin Muhammad Shahib Mirbath (d. 653 H/1255 AD), Imam Muhammad bin Said Basyukail (d. w.700 $\mathrm{H} / 1300 \mathrm{AD}$ ), which was then continued by the fuqaha (religious experts) from their descendants such as Alu Bafadl, Alu Bamakhramah, Sayyid Abdurrahman bin Mazru', Alu Baqusyair, Alu al-Saqqaf, Said Ba'asyin, Abdullah Basaudan, Abdurrahman alFamous, and many others. They also helped establish many mosques and Islamic boarding schools as places of learning religious sciences, especially in the science of jurisprudence in the Syafii's madzhab. Thus, further confirming that their role in the spread of the Shafii's madzhab in various places, including in the archipelago was not in doubt. 55 This was in accordance with the opinion of $\mathrm{KH}$ Hasyim Asyari, which he wrote in the treatise of the Sunnah wa Jamaah. ${ }^{56}$

Interestingly, in historical facts, the Syafii's madzhab has been developing since the beginning of the entry of Islam in the archipelago in the 9th century AD, and it was also recorded by Ibn Battuta when he stopped at the Kingdom of Samudera Pasai. He said that the fuqaha who existed at that time were embracing Shafii's madzhab.57 Along with the growth of the Islamic empire in the archipelago and the increasing number of Alawiyyin scholars, the Syafii's Madzhab increasingly existed and developed in the archipelago. Even the figh books written by Nusantara scholars from time to time were books affiliated with the Shafii's madzhab such as Shirath al-Mustaqim by Shaykh Nururddin ar-Raniri, Miratu Thullab by Shaykh Abdurrauf Sinkili, Hidayah by alSalikin Shaykh Abdusshamad al-Falimbani,58 Nihayah Zain by Shaykh Nawawi alBantani, ${ }^{59}$ Hasyiyah al-Tarmasi by Shaykh Mahfuzh al-Tarmasi, ${ }^{60}$ and many others.

${ }^{54}$ Habib Zain Ibrahim Ibnu Sumaith, Al-Manhaj Al-Sawi Syarh Ushul Thariqah Al-Sadah Ali Ba A'alawi, I (Tarim: Dar Ilmi Wa Da'wah, 2008), 26; Al-Masyhur, Syamsu Al-Zhahirah Fi, 55.

55 Ibnu Sumaith, Al-Manhaj Al-Sawi, 27.

${ }^{56} \mathrm{Kh}$ Muhammad Hasyim Asy'ari, Risalah Ahli Al-Sunnah Wa Al-Jama'ah (Jombang: Maktabah Turats Islami, T.T.), 3.

${ }^{57}$ Dzulkifli Hadi Imawan, The History of Islam in Indonesia; Kontribusi Ulama Membangun Peradaban dan Pemikiran Islam di Indonesia, I (Yogyakarta: Diva Press, 2021), 10.

58 Dzulkifli Hadi Imawan, "The Intellectual Network of Shaykh Abdusshamad AlFalimbani and His Contribution in Grounding Islam in Indonesian Archipelago At 18th Century Ad," Millah: Jurnal Studi Agama 18, No. 1 (31 Desember 2018): 31-50, https://doi.org/10.20885/millah.vol18.iss1.art3.

59 Dzulkifli Hadi Imawan, "Indonesian Ulama and Their Academic and Da'wa Contribution in the Islamic World in the 19th Century," Indonesian Journal of Interdisciplinary 
As for the faith, the Alawiyyin scholars are followers and propagators of the Ahlussunnah wal Jama'ah Asyairah creed, which was built by Imam Abu Hasan alAsy'ari in tearing down the arguments of groups that deviated from the teachings of the Prophet Muhammad. ${ }^{61}$ This teaching then spread in Yemen and was able to replace the Ibadiyah Khawarij teachings that had developed in Yemen before the arrival of Sayyid Ahmad al-Muhajir. From Yemen, the Alawiyyin scholars who preached in the archipelago also taught the Ahlu Sunnah wa Jamaah creed to the Javanese community. This dismissed the opinion of historians such as Rahman Zainudin and Widji Saksono, who believed that the creed of the Alawiyin scholars was Shiah.62 Thus, it needs to be emphasized that the Alawiyyin scholars or those in Java known as Walisongo were scholars who believed in Ahlu Sunnah wa Jamaah as the scholars who were their predecessors.

As for the issue of tariqat, according to Habib Zain, many of the Alawiyyin families followed the manhaj compiled by Imam Ghazali and Imam Syadzili as a way to God but did not deny the ideas of another tariqat that developed in the Arabian Peninsula. ${ }^{63}$ Imam Ghazali's convenience was the influence of his teachers, such as Abu Ma'ali al-Juwaini, and also Al-Baqilaniy, who were known as the assistants to the Ash'ari school. ${ }^{64}$

The integration of the thoughts of the Syafii's madzhab in the field of Islamic law, Asyairah's creed, and the Sunni Sufism of Ghazaliyah and Syadziliyah became da'wah material taught by Alawiyyin scholars when they preached or grounded Islam in Indonesia because this school was able to explain God's relationship with humans and taught it with peace. 65

This could be seen very clearly since the beginning to the end in the Islamic kingdoms in the archipelago starting from Peureulak, Samudera Pasai, Aceh Darussalam, Demak, Cirebon, Banten, Mataram, Palembang, Banjar, and others. All of them in enforcing Islamic law relied on Islamic law contained in the Shafii's madzhab as practiced by Shaykh Hamzah Fansuri, Shaykh Syamsuddin As-Sumatrani, ${ }^{66}$ Shaykh Abdurrauf al-Sinkili in the Kingdom of Aceh Darussalam, ${ }^{67}$ Shaykh Yusuf al-Makassari

Islamic Studies (Ijiis) $1, \quad$ No. $2 \quad$ (14 $\quad$ Februari $\quad 2019):$ 15-220,
https://doi.org/10.20885/ijiis.vol1.iss2.art8.

${ }^{60}$ Dzulkifli Hadi Imawan, "The Contribution of Syaikh Muhammad Mahfuzh Al-Tarmasi in the Development of Intelectual-Spiritual Pesantren in Indonesia in The 20th Century," Santri Journal of Pesantren and Fiqh Sosial I, No. I (2020): 13, https:/ / doi.org/10.35878/santri.v1i1.200.

61 Mustafa Kamal Bin Amat Misra, et al., "Appraisal of Human Acts Discourse Among Ashā'Irah Scholars," Humanities E Social Sciences Reviews 7, No. 4 (17th of September 2019): 35963, https://doi.org/10.18510/hssr.2019.7446.

62 Kholili Hasib, "Menelusuri Mazhab Walisongo," Tsaqafah 11, No. 1 (30"t of November 2015): 137-50, Https:/ / Doi.Org/10.21111/Tsaqafah.V11i1.257.

63 Ibnu Sumaith, Al-Manhaj Al-Sawi, 27-28.

${ }^{64}$ Misra, et al., "The Appraisal of Human Acts Discourse among Ashā'Irah Scholars."

65 "The Role of Ahl Al-Sunnah Wa Al-Jama'ah As Manhaj (Predecessor) and Mazhab (Sect) on Progressing of World's Civilization," Journal of Critical Reviews 7, No. 02 (1 st of January 2020), https:/ / doi.org/10.31838/jcr.07.02.130.

${ }^{66}$ Oman Fathurahman, "Itḥāf Al-Dhakī by Ibrāhīm Al-Kūrānī: A Commentary of Waḥdat Al- Wujūd for Jāwī Audiences," Archipel 81, No. 1 (2011): 177, https://doi.org/10.3406/arch.2011.4274.

67 Eri Rosatria, "Alāqat Harakat Nashr Al-Islām Wa Al-Tarbīyah Al-Islāmiyyah Fī Șultanah Aceh," Studia Islamika 3, No. 1 (1996): 133, https:/ / doi.org/10.15408/sdi.v3i1.815. 
in the Kingdom of Banten, ${ }^{68}$ Shaykh Muhammad Arsyad al-Banjari in the Kingdom of Banjar, ${ }^{69}$ also Shaykh Muhammad Mahfuzh al-Tarmasi, and Shaykh Nawawi alBantani in the pre-independence era of Indonesia. ${ }^{70}$

It was also increasingly clear that the relationship between the scholars of the archipelago and the Sayyid or habaib of Rasulullah's descendants from the Alawiyyin family both in the archipelago itself and in the Arabian peninsula; Hadramaut, Doha, Jeddah, Makkah, Madinah, Egypt, Damascus, Turkey, were interwoven based on the integration of the Shafi'i's madzhab, Asya'riyah's creed, and Sunni Sufism.

Among the evidence for all of that was the works of the scholars of the archipelago from the early days to the present that always explain these three main things; Shafi'i's figh, Ash'ari creed, and Sunni Sufism, as s intermediary in facilitating the study of Islam and grounding it in the archipelago as taught by the Prophet Muhammad which was accepted by the companions and passed on by the scholars from generation to generation.

\section{Conclusion}

Alawiyyin scholars were recorded in the history of Islam in the Indonesian archipelago as scholars who contributed greatly to the intellectual-spiritual development of Islam in the archipelago. Their presence in the archipelago was believed to have existed since the time of Daulah Umawiyah, and more and more when entering the 14th and 15th centuries AD in the archipelago. They played a major role in the Islamization of the archipelago, which was seen in their participation in building Islamic kingdoms in the archipelago such as the Kingdom of Demak, the Kingdom of Malacca, the Kingdom of Palembang, and others. In addition, the Alawiyyin scholars also succeeded in grounding the aqidah of Ahlussunnah wal Jamaah, the Syafii's Madzhab, and the Sufism's Order to the people of the archipelago. Furthermore, the integration of these thoughts was able to realize the people of the archipelago who love peace and compassion

\section{E. Acknowledgments}

The authors would like to thank everyone who was involved from the beginning until the end of the process and Universitas Islam Indonesia who has supported morally and materially. This includes our colleagues who gave feedbacks, as well as the editorial team and the reviewers who handled the manuscript and provided valuable insights in improving it further.

\section{F. Author Contributions Statement}

DH designed, conceptualized, and led the project. LN cleaned and prepared the data. DH and LN performed the statistical analysis and wrote the results, findings, and discussion. Both DH and LN wrote and edited the manuscript[.]

\footnotetext{
68 Awis Kami, "Al-Ṭașawwuf Fī Indūnīsīyā: Dirāsah Li Nuskhah Al-Kitāb Mațālib AlSālikīn Ta'lîf Yūsuf Al-Makāsārī," Studia Islamika 3, No. 2 (1996), https://doi.org/10.15408/sdi.v3i2.810.

${ }^{69}$ Muhammad Iqbal and Shahid Rahman, "Arsyad Al-Banjari's Dialectical Model for Integrating Indonesian Traditional Uses into Islamic Law," Argumentation 35, No. 1 (1 $1^{\text {st }}$ of March 2021): 73, https://doi.org/10.1007/s10503-020-09526-y.

${ }^{70}$ Muh Amïruddin, "Hadis Biliminin Endonezya'ya Girişi Ve Gelişmesine Mahfûz EtTermesî Ve Hâşim Eş'arî'nin Katkısı," Cumhuriyet İlahiyat Dergisi 24, No. 3 (15 th of December 2020): 1333, https:// doi.org/10.18505/cuid.767488.
} 


\section{REFERENCES}

Abdul Aziz Algeriani, A.M., dan M. Mohadi. "The House of Wisdom (Bayt alHikmah), an educational institution during the time of the Abbasid dynasty. A historical perspective." Pertanika Journal of Social Sciences and Humanities 27, no. 2 (2019): 1297-1313.

Al-Damasyqi, Syamsuddin Abu Abdillah Muhammad Abu Thalib al-Anshari. Nukhbah al-Dahr fi 'Ajaib al-Barr wa al-Bahr. Turs: Matba'ah Imritoriyah, 1881.

Al-Hamid, Shalih bin Ali. Rihlah Jawa al-Jamilah wa Qisshah Dukhul al-Islam ila Syarq Asia. I. Shan'a: Dar Kutub, 2002.

Ali al-Masyhur, Abu Bakar al-'Adani. Al-Imam Muhammad Shahib Mirbath. Adn: Markaz al-Ibda' al-Tsaqafi, 2002.

Ali al-Masyhur, Abu Bakar al-'Adani. Al-Ustadz al-A'zham al-Faqih al-Muqaddam (574653 H). II. Adn: Markaz al-Ibda' al-Tsaqafi, 2003.

Al-Idrisiy, Syarif Abu Abdillah Muhammad bin Muhammad bin Abdullah bin Idris alHasani. Nuzhatu al-Musytaq fi Ikhtiraq al-Afaq. Kairo: Maktabah Tsaqafah Diniyyah, 2002.

Al-Ja'fari, Bassyar. Auliya al-Syarq al-Ba'id Asathir Majhulah fi Aqadli al-Ma'murah; Riwayat Tarikhiyah Haula Kaifiyyah Intisyar al-Islam fi Arkhabil al-Malayu. I. Damaskus: Dar Thalas, 2002.

Al-Masyhur, Sayyid Abdurrahman Muhammad Husain. Syamsu al-Zhahirah fi Nasabi Ahli al-Bait min Bani Alawiy Furu' Fathimah al-Zahra' wa Amirul Mukminin Ali Radliyallah 'anhu. I. Jeddah: Alam Ma'rifah, 1984.

Amïruddin, Muh. "Hadis Biliminin Endonezya'ya Girişi ve Gelişmesine Mahfûz etTermesî ve Hâşim Eş'arî́nin Katkısı." Cumhuriyet İlahiyat Dergisi 24, no. 3 (15 th December 2020): 1333-54. https:/ / doi.org/10.18505/cuid.767488.

Amrizal, Amrizal. "Dimensi Sufistik Dalam Pandangan Hidup Orang Melayu." Akademika: Jurnal Pemikiran Islam 21, no. 2 (16 Oktober 2016): 275-90.

Arnold, Sir Thomas Walker. Al-Da'wah ila al-Islam; Bahts Fi Tarikh Nasyri al-'Aqidah alIslamiyah. Translated by Hasan Ibrahim Hasan and Abdul Majid Abidin. III. Kairo: Maktabah Nahdlah Mishriyah, 1935.

Asy'ari, KH Muhammad Hasyim. Risalah ahli al-Sunnah wa al-Jama'ah. Jombang: Maktabah Turats Islami, t.t.

Azra, Azumardi. Jaringan Ulama Timur Tengah dan Kepulauan Nusantara Abad XVII \& XVIII. Jakarta: Prenada Media Grup, 2013.

De Graaf, H.J, dan TH Pigeaud. Kerajaan Islam Pertama di Jawa; Tinjauan Sejarah Politik Abad XV dan XVI; De Eerste Moslimse Vorstendommen op Java, Studien Over de Staatkundige Geschiedenis van de 15 de en 16 de Euw. Edited by Eko Endarmoko and Jaap Erkelens. IV. Jakarta: Grafiti, 2001.

Farida, Umma. "Islamisasi di Demak Abad XV M: Kolaborasi Dinamis Ulama-Umara dalam Dakwah Islam di Demak." Accessed on 1st of November 2021. https:// doi.org/10.21043/at-tabsyir.v3i2.1649.

Fathurahman, Oman. "Itḥāf al-dhakī by Ibrāhīm al-Kūrānī: A Commentary of Waḥdat al- Wujūd for Jāwī Audiences." Archipel 81, no. 1 (2011): 177-98. https://doi.org/10.3406/arch.2011.4274.

Fournié, P. "Rediscovering the Walisongo, Indonesia: A Potential New Destination for International Pilgrimage." International Journal of Religious Tourism and Pilgrimage 7, no. 4 (2019): 77-86. 
Gani, A. "Pendekatan Sufistik Dalam Pendidikan Islam Berwawasan Perdamaian." Akademika: Jurnal Pemikiran Islam 23, no. 2 (25 th of November 2018): 387-412.

Harisudin, Muhammad Noor. "Islām wa fiqh Nusantara: al-Tanāfus 'alá al-huwīyah wa 'alāqat al-sulțah wa al-ramz al-dīnī li jam'īyah Nahdlatul Ulama." Studia Islamika 24, no. 3 (31 st of December 2017): 503-54. https:// doi.org/10.15408/sdi.v24i3.4324.

Hasib, Kholili. "Menelusuri Mazhab Walisongo." TSAQAFAH 11, no. 1 (30th of November 2015): 137-50. https://doi.org/10.21111/tsaqafah.v11i1.257.

Ibnu Khurdadzbah, Abu Qasim Ubaidullah bin Abdullah. Al-Masalik wa al-Mamamlik. Leiden: Briel, 1889.

Ibnu Sumaith, Habib Zain Ibrahim. Al-Manhaj al-Sawi Syarh Ushul Thariqah al-Sadah Ali Ba A'alawi. I. Tarim: Dar Ilmi wa Da'wah, 2008.

Imawan, Dzulkifli Hadi. "The Contribution of Syaikh Muhammad Mahfuzh AlTarmasi in the Development of Intelectual-Spiritual Pesantren in Indonesia in the 20th Century." Santri Journal of Pesantren and Figh Sosial I, no. I (2020): 13. https:// doi.org/10.35878/santri.v1i1.200.

Imawan, Dzulkifli Hadi. "Indonesian Ulama and Their Academic and Da'wa Contribution in the Islamic World in the 19th Century." Indonesian Journal of Interdisciplinary Islamic Studies (IJIIS) 1, no. 2 (14 th of February 2019): 15-220. https:// doi.org/10.20885/ijiis.vol1.iss2.art8.

Imawan, Dzulkifli Hadi. The History of Islam in Indonesia; Kontribusi Ulama Membangun Peradaban dan Pemikiran Islam di Indonesia. Yogyakarta: Diva Press, 2021.

Imawan, Dzulkifli Hadi. The History of Islam in Indonesia; Kontribusi Ulama Membangun Peradaban dan Pemikiran Islam di Indonesia. I. Yogyakarta: Diva Press, 2021.

Imawan, Dzulkifli Hadi. "The Intellectual Network of Shaykh Abdusshamad AlFalimbani and His Contribution in Grounding Islam in Indonesian Archipelago at 18th Century AD." Millah: Jurnal Studi Agama 18, no. 1 (31 ${ }^{\text {st }}$ of December 2018): 31-50. https:// doi.org/10.20885/millah.vol18.iss1.art3.

Iqbal, Muhammad, dan Shahid Rahman. "Arsyad Al-Banjari's Dialectical Model for Integrating Indonesian Traditional Uses into Islamic Law." Argumentation 35, no. 1 (1 Maret 2021): 73-99. https:/ / doi.org/10.1007/s10503-020-09526-y.

Kami, Awis. "Al-Țașawwuf Fī Indūnīsīyā: Dirāsah Li Nuskhah al-Kitāb Mațālib alSālikīn Ta'lîf Yūsuf al-Makāsārī." Studia Islamika 3, no. 2 (1996). https:// doi.org/10.15408/sdi.v3i2.810.

Kusmana, Kusmana. “Al-Tijārah Wa al-Da'wah al-Islāmīyah: Dirāsah Li Qaḍiyati Dukhūl al-Islām Fī Indūn̄isīyā." Studia Islamika 7, no. 3 (2000). https:// doi.org/10.15408/sdi.v7i3.704.

Lambourn, Elizabeth. "From Cambay to Samudera-Pasai and Gresik-the export of Gujarati grave memorials to Sumatra and Java in the fifteenth century C.E." Indonesia and the Malay World 31, no. 90 (1 ${ }^{\text {st }}$ of Juli 2003): 221-84. https:// doi.org/10.1080/1363981032000165903.

"Malacca Mosque: The Aesthetics of Old Mosques in Malaysia | Mediterranean Journal of Social Sciences," $5^{\text {th }}$ of August 2020. https://www.richtmann.org/journal/index.php/mjss/article/view/5216.

Meerangani, Khairul Azhar. "Peranan Ulama Dalam Penyebaran Ajaran Islam Di Pulau Besar, Melaka (The Role of Muslim Scholars in Spreading the Teaching of Islam in Pulau Besar, Melaka)." Journal of Al-Tamaddun 14, no. 2 (17 Desember 2019): 65-74. https:/ / doi.org/10.22452/JAT.vol14no2.6.

Misra, Mustafa Kamal Bin Amat, Nurhanisah Binte Senin, Mohd Manawi Bin Mohd Akib, Abdull Rahman Mahmood, and Jaffary Awang. “Appraisal Of Human 
Acts Discourse Among Ashā'Irah Scholars." Humanities $\mathcal{E}$ Social Sciences Reviews 7, no. 4 (17th of September 2019): 359-63. https://doi.org/10.18510/hssr.2019.7446.

Mukaffa, Zumrotul. "A New Account On The Portrait Of Ibrahim Asmarakandi And His Sufism Approach In Islamization Of Java." Journal Of Indonesian Islam 11, no. 1 (9th of July 2017): 175-200. https:/ / doi.org/10.15642/JIIS.2017.11.1.175-200.

Mu'nis, Husain. Athlas Tarikh al-Islam. I. Mesir: Az-Zahra' li al-I'lam al-'Arabi, 1987.

Nashir, Haedar, dan Mutohharun Jinan. "Re-Islamisation: The Conversion of Subculture from Abangan into Santri in Surakarta." Indonesian Journal of Islam and Muslim Societies 8, no. 1 (2nd of July 2018): 1-28. https:// doi.org/10.18326/ijims.v8i1.1-28.

Ninsiana, Widhiya. "Islam Dan Integrasi Sosial Dalam Cerminan Masyarakat Nusantara." Akademika: Jurnal Pemikiran Islam 21, no. 2 (16 th $^{\text {th }}$ October 2016): 357-76.

Nurhisam, Luqman, dan Mualimul Huda. "Islam Nusantara: A Middle Way?" QIJIS (Qudus International Journal of Islamic Studies) 4, no. 2 (30th of November 2016): 152-66. https:/ / doi.org/10.21043/ qijis.v4i2.1763.

Rosatria, Eri. “'Alāqat Harakat Nashr al-Islām Wa al-Tarbīyah al-Islāmiyyah Fī Șultanah Aceh." Studia Islamika 3, no. 1 (1996). https:// doi.org/10.15408/sdi.v3i1.815.

sairafi, Sulaiman al-Tajir al-. 'Ajaib al-Dunya wa Qiyas al-Buldan al-Mansub li Sulaiman alTajir 237H/851 M. Disunting oleh Saif Syahin Marikhi. Qatar: Markaz Zayid li Turats wa Tarikh, t.t.

Saqqaf, Ahmad al-. Tarikh al-Islam fi Banten; Al-Mukhtar al-Mashun min 'Alam al-Qurun Mukhtarat Tis'ah 'Asyara Kitaban. Jeddah: Dar Andalus Khadra', t.t.

Setiawan, Ahmad Yusuf. "Karya Sastra Sunan Giri dalam Perspektif Dakwah Islam." An-Nida: Jurnal Komunikasi Islam 7, no. 2 (2nd of Juli 2015). https:// doi.org/10.34001/an.v7i2.755.

Suparto, Suparto, Halid Halid, dan Samsu Adabi bin Mamat. "Bani Alawiyyin In Indonesia And The Malay World: Network, Development and the Role of Institution in Transmitting the Peaceful Mission of Islam." JOURNAL OF INDONESIAN ISLAM 13, no. 2 (1 $1^{\text {st }}$ of Desember 2019): 267-96. https:// doi.org/10.15642/JIIS.2019.13.2.267-296.

Susilo, Agus, dan Ratna Wulansari. "Peran Raden Fatah dalam Islamisasi di Kesultanan Demak Tahun 1478-1518." Tamaddun: Jurnal Kebudayaan Dan Sastra Islam 19, no. 1 (28 th of June 2019): 70-83. https:// doi.org/10.19109/tamaddun.v19i1.3401.

Thahir Al-Haddad, Sayyid Alawi. Al-Madkhal ila Tarikh al-Islam fi asy-Syarq al-Aqsha. I. Jeddah: 'Alam Ma'rifah, 1985.

"The Role Of Ahl Al-Sunnah Wa Al-Jama'ah As Manhaj (Predecessor) And Mazhab (School Of Thought) On Progressing Of World's Civilization." Journal of Critical Reviews 7, no. 02 (1 January 2020). https:/ / doi.org/10.31838/jcr.07.02.130.

Udi, Abu Hasan Ali bin Husain bin Ali al-Mas'. Muruj adz-Dzahab wa Ma'adin al-Jauhar. I. Beirut: Maktabah 'Ashriyah, 2005. 